\title{
Asian apparel brands' internationalization: the application of theories to the cases of Giordano and Uniqlo
}

Hongjoo Woo* and Byoungho Jin

*Correspondence:
h_woo@uncg.edu
Department of Consumer, Apparel,
and Retail Studies, Bryan School of
Business and Economics, The
University of North Carolina at
Greensboro, 210 Stone Building,
Greensboro, NC 27402-6170, USA

Greensboro, NC 27402-6170, USA

\begin{abstract}
How did Asian apparel brands internationalize in the competitive global apparel market? Although Asian brands are becoming global, most of previous research on internationalization was limited to the cases of the brands having Western-origins. This study aimed to explore the internationalization patterns of two leading Asian apparel brands, Giordano and Uniqlo, applying existing internationalization theories. For analysis, a case study approach was adopted by analyzing the secondary data from company reports, websites, and trade publications, following the previous case studies.

Today Giordano and Uniqlo are operating more than 2,000 stores worldwide. They internationalized to the geographically close markets first, and then extended the businesses to far distance countries following the Uppsala model. Both brands are focusing on Asian developing countries recently. The two brands' integrated supply chains and the positioning concept as basic, quality apparel at low price contributed to facilitating their internationalization. The findings confirm the existing internationalization theories and add the empirical cases of Asian brands to literature. This study also provides a managerial implication for the other brands seeking internationalization opportunities, especially for the brands with Western-origins, that need to compete with growing Asian competitors in global marketplaces.
\end{abstract}

Keywords: Giordano; Uniqlo; Internationalization; the Uppsala model; the OLI model

\section{Introduction}

The Asian apparel industry keeps growing in global markets while the global apparel industry becomes highly volatile with increasing internationalization (Lopez \& Fan 2009). One noticeable trend of the industry is an active international expansion of Asian apparel brands. Two leading Asian brands, Giordano from Hong Kong and Uniqlo from Japan, are the cases. They gained early attention by Western media compared to other Asian retailers; for instance, Giordano's story has been discussed as an independent chapter in the Western marketing textbook (Wirtz 2007) and Uniqlo's flagship opening on the 5th avenue in New York City received a write-up in U.S. news (e.g., Dickler 2011). Giordano earned approximately $70 \%$ of its total sales in foreign countries in the recent term (Giordano Interim Report 2013), although the company's total sales currently show a stability after its 25 years of business (see Figure 1). The net sales of Fast Retailing (the owner of Uniqlo) has continuously increased, and the sales of Uniqlo International was almost two times higher than the

\section{Springer}

(c) 2014 Woo and Jin; licensee Springer. This is an open access article distributed under the terms of the Creative Commons Attribution License (http://creativecommons.org/licenses/by/2.0), which permits unrestricted use, distribution, and reproduction in any medium, provided the original work is properly cited. 


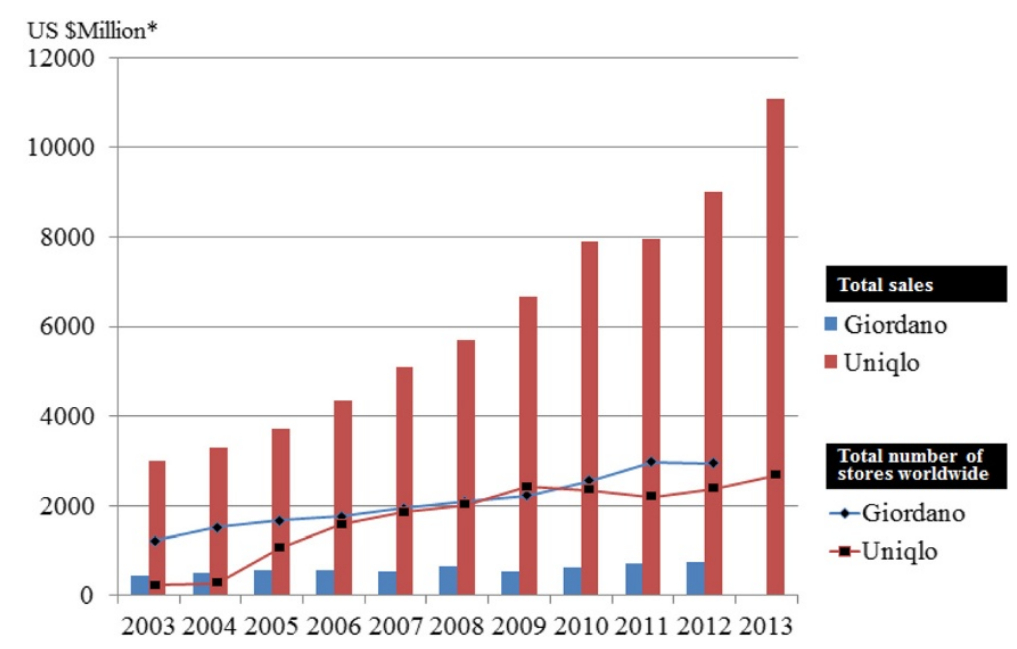

Figure 1 Giordano and Uniqlo's annual sales and the number of stores worldwide over the recent 10 years. ${ }^{*}$ Original sales data in \$HK for Giordano and in Japanese Yen for Uniqlo were exchanged to \$US by the following currency rates of the data collection period: $1 \$ H K=\$ 0.13,1$ Yen $=\$ 0.0097$ (as of March 2014). **Giordano's latest available annual data was the year of 2012 at the time of data collection.

sales of Uniqlo Japan in the recent term (Uniqlo Annual Report 2013). The total number of stores worldwide keeps increasing for both companies as Figure 1 shows. Now it is apparent that these Asian apparel brands are becoming global.

Despite the fast-growing presence of Asian apparel brands in the global markets, Asia has been considered simply a producer or manufacturer in the supply chain providing cheap labor. The discussion of Asian apparel brands' internationalization is considerably lacking in literature. Most of the studies on apparel brands' internationalization are performed for specific Western apparel brands with the focus on their marketing strategies, such as the cases of Levi's and Zara e.g., (Bhardwaj et al. 2011; Jackson \& Sparks 2005; Lopez \& Fan 2009; Vrontis \& Vronti 2004). These brands might have higher brand awareness and more stable brand positions in the global markets for internationalization compared to Asian brands. In this context, how did Asian brands internationalize in the global market? What specific strategies facilitated their internationalization? Are those strategies similar or different to Western competitors that have already been studied?

To answer these questions, this study aims to analyze the internationalization patterns of two pioneer Asian brands, Giordano and Uniqlo, with applying existing internationalization theories and identifying the strategies that facilitated their internationalization. For this, the current study adopted a case study approach by analyzing data from secondary sources such as company reports, websites, and trade publications that were commonly used by previous internationalization case studies (e.g., Childs \& Jin 2014; Lopez \& Fan 2009; Vrontis \& Vronti 2004). The findings of this study will not only close the theoretical gap of Asian brands' internationalization in literature, but also provide a useful information base for branding practitioners of the former Asian brands' internationalization cases.

This study is structured as follows: First, the internationalization theories as the theoretical framework and previous case studies of apparel brands' internationalization in literature will be reviewed. Next, Giordano and Uniqlo's internationalization patterns from the onset will be analyzed applying the internationalization theories. Two brands' common strategies for internationalization will be identified and contrasted with their 
major competitors such as global fast fashion brands. Discussion and implications will also be included.

\section{Literature review}

\section{Theoretical framework: internationalization theories}

This study analyzes the internationalization of two brands based on existing internationalization theories as a theoretical framework. Internationalization has been defined as "the process of increasing involvement in international operations" (Anderson 1997; Welch \& Luostarinen 1988, p. 36). Here, "increasing involvement" may indicate a firm's extended entries to international markets. The major focus of internationalization literature has been foreign market entries, with the discussion of market selection (e.g., Anderson 1997; Johanson \& Vahlne 1977). With this support, internationalization discussed in this study mainly focuses on the selected brands' foreign market entries.

There are major internationalization theories developed to explain a firm's internationalization process. One of the most well-known internationalization theories is the Uppsala model (also called the Stage model), which explains internationalization as an incremental process of firms increasing their involvements in international operations in a stepwise manner (Bhardwaj et al., 2011). According to Forsgren (2002), the Uppsala model is based on two assumptions: the resource-based theory and the incremental process. First, the Uppsala model is rooted in the resource-based theory (Anderson \& Kheam 1996), which views the lack of knowledge about foreign markets (i.e., market uncertainty) as the major obstacle of firms' internationalization (Forsgren 2002). To reduce this market uncertainty, firms aim to acquire information about international markets and one of the best ways of doing this is by gaining experiences through operating businesses in the market; which is often referred to experiential knowledge. This logic provides the reason for the second assumption, the incremental process. After acquiring market experiences, as known as 'learning by doing', firms can extend their international business to a larger scale and to further markets. In other words, the more the firm knows about the market, the lower the perceived market uncertainty will be, and the higher the level of internationalization occurs in the market (Forsgren 2002). In this incremental manner, the Uppsala model explains that the basic pattern of firms' internationalization is to start to invest in just one or in a few neighboring countries, and then to enter new markets with greater psychic distance and market uncertainty (Forsgren 2002; Johanson \& Vahlne 1990). The essence of the Uppsala model is that a company's experiential knowledge learned from operating businesses in home and close markets allow its further expansion to a broader scope (Johanson \& Vahlne 1977).

While a considerable amount of studies support the incremental process of the Uppsala model, some studies argued that firms are not necessarily able to apply similar strategies obtained from neighboring markets to the further international market (Bell et al. 2001; Bhardwaj et al., 2011). They suggest that firms expand straight to far markets as a strategic movement using their organizational advantages (Bell et al., 2001).

Another widely known internationalization theory, the OLI model proposed by Dunning (1977), supports this viewpoint. He provides three competitive advantages of a firm, Ownership (O), Locational (L), and Internalization (I) advantages, and argued that these three factors determine the firm's entry to international markets (Dunning 1988; Anderson 1997). First, Ownership (O) advantages refer to the assets that are specific to the nature 
and nationality of the owner. Locational (L) advantages include the host countries' market attractiveness such as high market potential, favorable market environments and regulations affecting the business in the countries (Zhao \& Decker 2004). Lastly, Internalization (I) advantages arising from transferring ownership assets across international operations within the organization also influence a firm's internationalization (Zhao \& Decker 2004). So according to the OLI model, firms internationalize when one, some, or all of these three advantages are met, although this does not necessarily follow incremental steps. For example, a firm can internationalize to the market because the owner of the firm has substantial knowledge of the market $(\mathrm{O})$, because the market has high potential and a friendly regulation system (L), and/or because the firm has an integrated supply chain that enables the firm to easily transfer organizational advantages across the stages of supply chains (I). Agarwal and Ramaswami (1992) empirically showed the selected American service firms' internationalization that is independently or jointly affected by these three advantages.

\section{Previous studies on apparel brands' internationalization}

Previous studies investigated apparel brands' internationalization. Some of the studies analyzed brands' internationalization patterns based on theories, but most of the studies did not. Bhardwaj et al. (2011) analyzed the internationalization of Spanish fashion brand Zara based on the internationalization theories. The study argued that it was possible for Zara to internationalize aggressively in a short time due to its vertically integrated supply chain system that easily controls the whole supply chain, and this shows the Internalization advantage of the OLI model. Zara was also studied by Lopez and Fan (2009), who described that Zara's internationalization pattern matches with the Stage model as it entered European countries first and then expanded to the Asian markets. Wigley et al. (2005) explored the success factors of the internationalization of British brands comparing to American brands and explained that unique brand concepts help their rapid internationalization. Also in Wigley and Chiang (2009)'s analysis on the internationalization practice of per una in Taiwan market compared to UK market, brand concept strategy was identified as an important factor in their internationalization. Specifically, the study noted that unique product design, pricing strategy, and maintaining brand's conceptual image are important in fashion brands' internationalization. Vrontis and Vronti (2004) looked at the internationalization of Levi's, and Jackson and Sparks (2005) studied Marks and Spencer's internationalization in Hong Kong market, but they were more focused on the brands' marketing mix strategies rather than analyzing the pattern of internationalization applying existing theories.

Overall, previous studies discussed apparel brands' internationalization but there were limited studies that analyzed the apparel brands' internationalization patterns based on existing internationalization theories. Moreover, most of the case studies were concentrated on the brands having Western-origins, and the cases of Asian apparel brands were substantially lacking in literature.

\section{Research objectives and design}

To close the research gap of Asian apparel brands' internationalization, the present study builds three research objectives. First, this study analyzes the internationalization patterns of two Asian apparel brands, Giordano and Uniqlo, based on the theoretical 
framework of the Uppsala model and the OLI model. Second, this study analyzes if there is any factors in common that facilitated the two brands' internationalization. Lastly, this study analyzes how these factors are similar or different with the two brands' global competitors having Western-origins, such as global fast fashion brands.

To address these objectives, the current study adopts a case study approach. Following the previous studies (e.g., Childs \& Jin 2014; Jackson \& Sparks 2005; Lopez \& Fan 2009; Vrontis \& Vronti 2004), the two brands, Giordano and Uniqlo's company data from secondary sources such as company reports, websites, trade publications, and news media were collected and analyzed. Although Giordano and Uniqlo were selected based on their relatively higher brand awareness compared to other Asian brands (e.g., Dickler 2011; Wirtz 2007) as this study is an early step of the research topic as Asian apparel brands' internationalization, more future studies on the other Asian brands will be important.

\section{Findings}

Company overviews

\section{Giordano}

Giordano International Limited (1981) is a Hong Kong brand of men's, women's, and children's quality apparel founded in 1981 (Khandelwal \& Saxena 2010). Giordano started as a manufacturer but today it is one of the most well-known and established apparel brands in the Asia Pacific region. The company sells its products under the multi-brands of "Giordano," "Giordano Concepts," "Giordano Junior," "Giordano Ladies," and "BSX" which targets young consumers. Giordano manages its overall business system by integrated business model, which includes manufacturing, franchising, and marketing (Khandelwal \& Saxena 2010).

Giordano is renowned for its basic apparel items; practical t-shirts, trousers, and comfortable denims. Initially, the brand set up operations to serve the casual wear needs of Asia's swelling young middle class, aiming for volume sales using the chain store format (Dibb 1996; Khandelwal \& Saxena 2010). The brand's marketing objective is to pursue a "value for money" positioning based on a combination of keen prices and customer satisfaction with quality products. Giordano has been able to sustain its value pricing by manufacturing most of its products in China where labor and factory costs are low, which is the close country to Hong Kong geographically and culturally. Based on these strategies, Giordano reported rapid growth in sales, which approached US \$366 million (HK\$ = 2,841) for the 6 first half year of 2013 (Giordano Interim Report 2013).

Giordano's initial international entry was Taiwan in 1983, two years after the company's establishment. Today, Giordano operates in more than 30 countries worldwide, including Mainland China, Hong Kong, Taiwan, South Korea, Singapore, Malaysia, Thailand, Indonesia, Australia, and the Middle East and employs over 8,000 staff with over 2,600 shops as of June, 2013 (Giordano Interim Report 2013).

Uniqlo

Established in 1984, Uniqlo is an apparel brand of Japanese global retailer, Fast Retailing. The retailer has grown fast by offering high-quality casual wear at low prices based on its vertically integrated business model, which spans product design, manufacture, distribution, and retail. During the recent ten years, total net sales increased approximately forty times (Uniqlo Annual Report 2013). The total net sales of Fast Retailing Group exceeded eleven million US dollars in the latest year (Uniqlo Annual Report 2013). Since 
2005, Fast Retailing has purchased multiple brands, the France-based women's fashion brand Comtoir des Contonniers, the French lingerie brand Princesse tam.tam, and the women's fashion brand Theory.

Uniqlo's first venturing into international markets happened in 2001. It now has operations in more than 12 countries including the United Kingdom, the United States, China, Hong Kong, South Korea, France, Singapore, and Russia. In fiscal year of 2010, Uniqlo had 808 stores in Japan and 136 stores internationally. Today, the total number of stores including Uniqlo and acquainted brands is approximately 2,449 worldwide with 23,982 full-time employees (Uniqlo Annual Report 2013).

\section{Analysis of the internationalization patterns of Giordano and Uniqlo}

Based on collected secondary data, Giordano and Uniqlo's internationalization patterns are organized in Figures 2 and 3 by the order of entry year. The entry year and the number of stores of each country are also marked next to each bar. Figures 2 and 3 revealed some common patterns as well as some differences between the two. Overall, the two brands' entries to international markets can be grouped into three periods that show a distinctive pattern, which are explained with applying existing internationalization theories as follows.

\section{Pattern 1: To Close Countries First}

The first internationalization pattern common to the two brands is that both started their efforts in relatively close countries. Giordano started internationalization in Taiwan first (1983), and then in Singapore (1985) and China (1992). These countries are not only geographically close, but culturally close as they use the same language, Chinese, and have a common Chinese population. Uniqlo also entered China (2002), South Korea (2004), and Hong Kong (2005) during its first few years of internationalization. Obviously, this pattern matches that of the internationalization theory, the Uppsala model (Stage model), which assumes that a firm starts its investment in a few neighboring countries, then expands its distribution to new markets with successively greater psychic distance after learning about foreign markets (Forsgren 2002; Johanson \& Vahlne 1990). This direction also supports

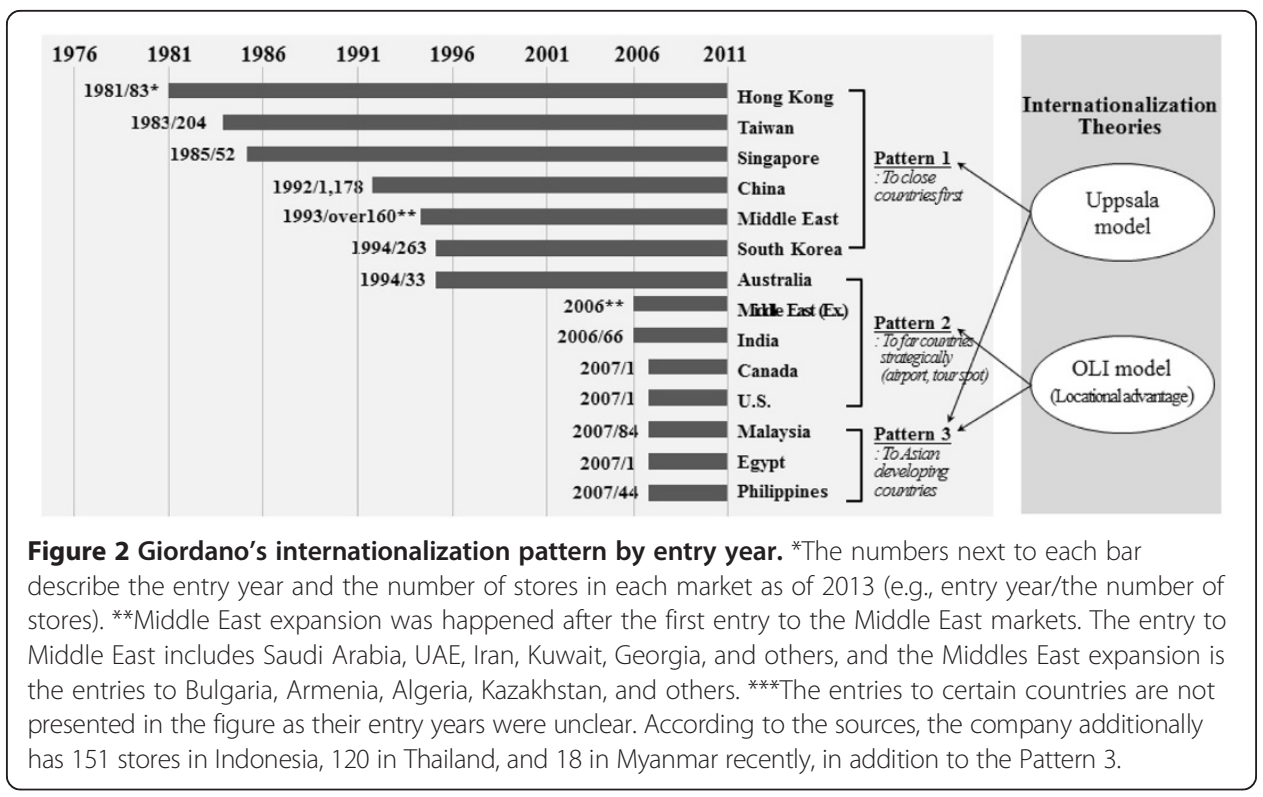




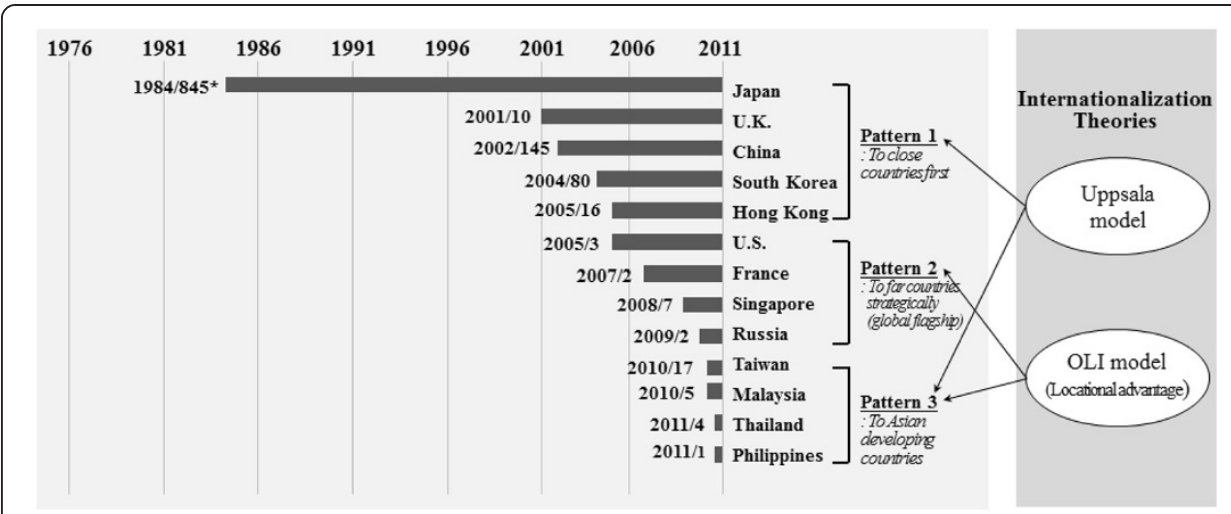

Figure 3 Uniqlo's internationalization pattern by entry year. *The numbers next to each bar describe the entry year and the number of stores in each market as of 2010 (e.g., entry year/the number of stores).

the previous study of Zara's incremental internationalization case in literature (i.e., Lopez \& Fan 2009). Uniqlo's expansion to the United Kingdom in 2001 as their first international market entry showed an exception to this model, but overall the two brands expanded to closer countries during the early period of their internationalization.

\section{Pattern 2: To Far Countries Strategically Next}

After expansion to geographically and culturally closer countries first, both brands expanded to countries with greater distances. Giordano extraordinarily entered Middle East countries (1994) including Saudi Arabia, UAE, and Iran right after entering to China (1993). The company even widely expanded its Middle East network to Kuwait, Georgia, Bulgaria, and other countries in 2006 in addition to entering Australia (1994) and India (2006). Likewise, Uniqlo entered the U.S. (2005), France (2007), and Russia (2009) after securing its position in Asian countries. The two brands, however, presented different movements in terms of their specific strategies.

Giordano paid attention to Middle East markets earlier than other fashion retailers with opening stores in Dubai, 1993. In terms of entry strategy, opening stores in dutyfree shops at airports, central tourist attractions near airports, and well-known tourist locations were found to be unique for Giordano. For the recent Egyptian market entry, it launched its first store in the City Stars Mall in Cairo, a big touristic spot as well as just minutes from the Cairo International Airport (Investor Relations News, Giordano website). Giordano also has stores in Dubai and Qatar airport duty-free shops. For the company, the stores at airports or central shopping districts play a role of exhibition and enhancing its reputation as a global brand among foreign travelers. Also, the purpose of this strategy was for further expansion to other distant markets near the Middle East countries with brand awareness built in international airports. Based on its initiate success, Middle East Giordano performed a large expansion seeking opportunities in Central Asia and Eastern Europe markets such as Kazakhstan, Bulgaria, and Georgia by Giordano Middle East in 2006.

In contrast, Uniqlo's strategy was somewhat different to the Giordano's. Uniqlo's major strategy for global markets was opening eventful flagship stores in iconic fashion cities in foreign far countries. Opening global flagship stores in New York (2006), London (2007), Paris (2009), and Shanghai (2010) was a key part of the company's strategy to boost recognition of the 
Uniqlo brand in global markets. Uniqlo has opened five global flagship stores with the latest and biggest one being in New York City's Fifth Avenue opened on October 21, 2011; this location has 89,000 square feet and features 100 dressing rooms and 50 cash registers (Truong 2011). For Uniqlo, the global flagship stores serve as hubs to spread the company's marketing message and concept of high-quality basics like a showcase, and are the announcement that they will enter that new market. Also, they are bridgeheads to expand business into faraway markets by enhancing the company's global reputation. Uniqlo plans to open more stores in major European cities, beginning with Germany and Spain (Uniqlo Annual Report 2010).

In analyzing this second pattern of movements, OLI model provides a good fit. Because geographic proximity can be a factor of Locational advantage but not a prerequisite, company's internationalization occurs when the market has high advantages considering other factors (Dunning 1988). For Giordano and Uniqlo, Middle East market and major fashion cities had Locational advantages in terms of their high potential in building global reputation and future expansion for further revenue. Their efforts to be a global company without following incremental stages also match with the previous studies (e.g., Bell et al., 2001; Bhardwaj et al., 2011). These movements follow the Stage model in terms of occurring after the first entries to Asian countries, but do not fit the model as the two brands extended to other Asian countries after entering far countries. The current focus on rising Asian countries is shown in the next pattern.

\section{Pattern 3: To Asian Developing Countries Recently}

The last internationalization pattern of the two brands is the recent focus on developing Asian countries. Giordano recently entered Malaysia (2007), Thailand, and the Philippines (2007) and reported that sales in those markets have notably increased as they expected (Giordano Interim Report 2011). Giordano also regarded the potential of the Indian market as considerable, so the company published a 3-year expansion plan for India in 2006 that has successfully extended the number of its Indian outlets since (Investor Relations News, Giordano website). Likewise, during the past two years, Uniqlo has aggressively entered Malaysia (2010), Thailand (2011), and the Philippines (2011). Recently, Uniqlo International earned approximately $70 \%$ of its total sales in Asia (Uniqlo Annual Report 2010). This movement is able to be explained by Locational advantage of OLI model, the high potential of Asian developing markets. Apparel and textile industries in developing Asian countries are anticipated to grow continuously and to reach a value of about \$1.8 trillion in 2014 (Datamonitor 2009). Also, because the brands can apply their experiential resources obtained from home and other Asian countries to these growing markets using market similarities, it corresponds with the Uppsala model as well. As the companies from the earliest developed Asian countries, Japan and Hong Kong, they are able to better understand the consumer needs and market environments in Asian developing countries than Western countries that are not sharing similar cultures or experiences. In other words, being Asian retailers gives them more advantages to utilize their experiential knowledge since Japanese and Hong Kong brands had been through the same industrial development stages.

\section{The strategies of Giordano and Uniqlo that facilitated internationalization}

In addition to the analysis of internationalization patterns, the noticeable strategies that facilitated Giordano and Uniqlo's internationalization were investigated. The analysis revealed two factors: 1) an integrated supply chain system driving the Internalization 
advantage of OLI model, and 2) the unique positioning on basic, quality apparel brands at low prices. These factors were compared further with their main competitors, global fast fashion brands, which have similar price lines and targets.

\section{Integrated supply chain}

Both Giordano and Uniqlo exhibit an integrated supply chain system in which the companies plan and control manufacturing of their own products and distribute and sell the products to their own specialty stores. From its start as a manufacturer in the 1970s, Giordano has operated its own manufacturing system, inventory system, and specialty stores. Although now about $95 \%$ of its merchandise is outsourced, it still maintains a main manufacturing operation that provides the other $5 \%$ of Giordano's merchandise needs (Khandelwal \& Saxena 2010) and controls it through the headquarters in Hong Kong. This headquarters operates as a platform to source from suppliers in the Chinese mainland, South Korea, and Singapore, and the company is able to sustain its value pricing by manufacturing most of its products in China where labor and factory costs are low. In this way, Giordano combines the advantages of the low-cost regional environment for the brand's 'value for money' concept, with Hong Kong's experience of just-in-time logistical systems and unsurpassed international marketing networks.

Uniqlo represents a more integrated supply chain system encompassing all stages of supply chain - from design and production to final sale to consumers. This system allows it to secure high-quality products at reasonable prices. For example, the company has exclusive partnership manufacturing factories such as Kaihara Corporation for denim and Toray Industries for fiber, to source a stable quality of products to stores. The brand even has its own R\&D centers for product development, and also outsources production, approximately 85\% of products from China (Uniqlo Annual Report 2010).

Previous studies (e.g., Bhardwaj et al., 2011; Lopez \& Fan 2009) found that firms' integrated supply chains contribute to rapid internationalization. The former Zara's case showed that controlling the entire production chain enabled the firm to have a faster turnaround as well as foreign market entries with franchising store format, using standardized marketing mix elements across outlets (Lopez \& Fan 2009). By managing various stages of the supply chain by themselves, they can supply qualified products securely at reasonable prices (Kim 2010). Also, the firms' controls over the entire supply chains facilitated their internationalization based on the Internalization advantage of OLI model; managing overall system makes it easy to transfer organizational assets across the international operations within the organization fast and consistently (Zhao \& Decker 2004), like a franchise retail store format.

\section{"Basic, Quality, and Cheap Apparel" works: the brand positioning concept}

Another shared strategy between Giordano and Uniqlo is that they positioned themselves with quality basic apparel products. Giordano's brand positioning is defined as "Unisex casual wear for all ages" (Wirtz 2007), and Uniqlo similarly promotes its "Made for all" at every store worldwide. First, Giordano understood there was a swelling number of middle class consumers who needed quality values and affordable prices that matched the frugal nature in the Asia region. With this understanding of the market, the company pursued a "value for money" positioning based on a combination of keen prices and basic quality products (Dibb 1996; Khandelwal \& Saxena 2010). The 
positioning strategy was successful among Asian customers with "guilt-free shopping" considering price compared to quality (Khandelwal \& Saxena 2010; Seno 1999).

Uniqlo's brand positioning concept also succeeded, as the high-quality basic casual with low prices. Uniqlo recognized the potential of everyday basic items such as T-shirts, socks, and jeans to coordinate with fashion items, although they were not normally considered the most exciting part of business but are found in every wardrobe (Economist 2010). Rather than tracing fast-changing fashion trends like fast fashion retailers, Uniqlo has focused on offering high-quality basic casual wear, such as their hit products - the fleece jacket and the 'Heattech' sweater (a high-technology sweater developed by Uniqlo that keeps the body warm). The company identifies these functional clothing items as 'key strategic products' and fulfills this strategy through operating its exclusive partnership manufacturing company. Uniqlo acknowledges that its positioning concept is important to be differentiated to global competitors like Zara, H\&M, or Gap. Nobuo Domae, vice president of Fast Retailing emphasized, "Everybody's focusing on style and trend today. But our focus is on quality" (Conti 2011).

This brand positioning concept might be useful for their internationalization in twofold: First, focusing on basic apparel design enabled them to be free from design localization across different foreign markets. Since the firms do not necessarily have to modify product designs to meet each market's taste, extending the business to international markets might be faster compared to competitors. Also, the concept caught a niche market of basic apparel as previous studies discussed (e.g., Wigely \& Chiang 2009; Wigley et al., 2005). If Giordano and Uniqlo targeted the same fashion apparel market with the global fast fashion retailers, their international extension might be more competitive when considering the current global market power of fast fashion retailers (e.g., Zara and H\&M). This point will be discussed more in the next section. In these contexts above, the two brands' positioning concepts can be debated as the driving force of their internationalization.

\section{A comparison with global fast fashion brands}

Fast fashion brands refer to the brands marketing short-lived latest fashion products at cheap price with a quick-response to changing fashion trends (Hayes \& Jones 2006). The global fast fashion brands, such as Zara, are Giordano and Uniqlo's competitors as having similar price lines and target consumers. Table 1 presents a comparison of Giordano and Uniqlo with global fast fashion brands. As Table 1 shows, the brands share the similarity of having an integrated supply chain system. On the other hand, Giordano and Uniqlo are

Table 1 Similarities and differences between Giordano, Uniqlo, and Global fast fashion brands

\begin{tabular}{|c|c|c|c|}
\hline \multicolumn{2}{|c|}{ Similarities/differences } & \multirow{2}{*}{$\begin{array}{l}\text { Asian fashion brands } \\
\text { (Giordano \& Uniqlo) }\end{array}$} & \multirow{2}{*}{$\begin{array}{l}\text { Global fast fashion brands } \\
\text { (e.g., Zara) } \\
\text { Trendy apparel following the latest } \\
\text { fashion }\end{array}$} \\
\hline Differences & Product design & & \\
\hline & Product assortment & $\begin{array}{l}\text { Narrow-and-deep assortment: } \\
\text { Small variety of styles but large } \\
\text { quantity in each style }\end{array}$ & $\begin{array}{l}\text { Broad-and-shallow assortment: Large } \\
\text { variety of styles but small quantity in } \\
\text { each style }\end{array}$ \\
\hline Similarity & Supply chain system & \multicolumn{2}{|c|}{$\begin{array}{l}\text { Integrated supply chain system which controls the whole stages } \\
\text { from manufacturing to distribution }\end{array}$} \\
\hline
\end{tabular}

Source: Developed by authors. 
somewhat different with fast fashion retailers regarding their positioning concept strategies as previously discussed. While fast fashion brands offer the latest fashion products with agility, Giordano and Uniqlo primarily carry basic apparels that are relatively apart from fashion trends, but focus on good quality and limited product assortment. In other words, they carry a 'narrow and deep' product assortment whereas fast fashion brands carry a 'broad and shallow' assortment. A 'narrow and deep' policy refers to buying a small number of styles in high volume, which is more efficient to manufacture in bulk costeffectively leading higher profits for the company and lower prices for the customers. Conversely, fast fashion brands' broad and shallow assortment policy offers a wide selection of styles in limited numbers per style, which allows a trendy fashion image but not necessarily a quality image (Goworek 2007). Therefore, Giordano and Uniqlo's narrowand-deep strategy differentiated from fast fashion let them attract the niche market, since global fast fashion brands were already serving the needs of short-living fashion items in most Asian markets. In other words, there was still a need for basic items at good value to coordinate with fashion items for consumers, and the two brands met this need well.

Giordano stores feature no more than 100 variants of 17 core items, whereas competing retailers might feature 200 to 300 items. As Ishwar Chugani, executive director of Giordano stated, "Our product strategy is a 'less is more.' We focus on providing a smaller range but offering the right choices for our customers" (Meshbah 2010). Likewise, Uniqlo produces small numbers of items in more than 10 colors focused on basic shirts and knits in good quality. Tadashi Yanai, president and CEO of Uniqlo said, "Our strength is high-quality basic clothing. We must proceed in a completely different way than H\&M or Zara, which both tend to pursue fashion trends" (Uniqlo Annual Report 2010). This strategy allows the brands to achieve an efficient inventory management system as well as quick response to market demands (Kim 2010) that are needed for integrated business model, which facilitates brands' internationalization.

\section{Discussion and implications}

Although Asian apparel brands are becoming highly global, the research on their internationalization was lacking in the literature. The analysis of Giordano and Uniqlo's internationalization in this study showed similar patterns of foreign market entry; they started with relatively close countries first, and then expanded to more distant countries aggressively with different strategies in specific. Giordano opened stores in duty-free shops and focused on expansion to the Middle East region, whereas Uniqlo focused on launching global flagship stores in fashion capitals. Recently, both companies have been focusing on the developing Asian countries having high market potential. The application of internationalization theories could explain the two Asian brands' internationalization patterns: the Uppsala model explains the first and the third patterns whereas the Locational advantage of the OLI model describes the second and the third patterns. In internationalization, the brands' integrated supply chain and the brand concept focusing on basic apparel facilitated their foreign market entries by increasing internalization advantage from OLI model and by shortening the time for design localization. This clearly contrasts with global fast fashion retailers that concentrate on fast turnover of fashion products, even though they share the commonality of the integrated supply chain. In conclusion, not only one theory, but multiple theories needed to be applied to explain the internationalization of Giordano and Uniqlo. 
Theoretically, the findings of this study add empirical cases of Asian brands to the internationalization literature that applied existing theories to the cases of specific brands (e.g., Childs \& Jin 2014; Lopez \& Fan 2009). In the previous case studies on global fast fashion brands such as Zara (Lopez \& Fan 2009), H\&M and New Look (Childs \& Jin 2014), the brands showed similar entry patterns to relatively close countries following the Uppsala model in the initial stage of internationalization. However, they recently showed a "born-global" movement which describes the aggressive expansion to foreign markets regardless of geographic and cultural proximities (Bell et al., 2001; Childs \& Jin 2014), which depicts a scattered distribution of entered markets all around the world. For this movement the existing Uppsala model alone does not provide a perfect description (Childs \& Jin 2014). The cases of Giordano and Uniqlo also supported the literature that any internationalization theory alone is not enough to explain their foreign market entry patterns, but several theories, such as the Uppsala model and the OLI model, are needed to explain their internationalization. In the current study, however, the two Asian brands showed that they are going back to neighboring Asian markets as the Uppsala model suggests, for the growing potential of emerging Asian countries. This difference might be interpreted by the global fast fashion brands' higher brand assets compared to the Asian retailers. Since global fast fashion brands started internationalization earlier and they already secured a more stable position in global markets than the Asian brands, they might possess more experiential knowledge, higher brand awareness, or brand equity, which drives a stable brand position in the market. This might enable them to enter diverse markets more aggressively now, compared to the Asian brands, as the Uppsala model explained that knowledge and experiences are the important resources of internationalization (Forsgren 2002). If so, the future question would be "are Asian brands going to follow the similar "born-global" movement with global fast fashion brands as they grow more?" This merits for future studies.

Practically, the findings provide implications especially for the global brands with Western-origins. Asian developing markets are one of the fastest growing markets with high potential, and the Asian brands (i.e., Giordano and Uniqlo) were focusing on this market with their advantages of experiential knowledge, geographical and cultural proximities. In the past, when global brands sought to enter developing markets, it was less competitive because it was a matter of competing with the other brands from Western-origins. Now, however, the brands must also compete with Asian players, which are already securing their positions with their advantages in the Asian market. To support this, there are additional cases of Asian brands that gain a significant success in Asian countries: South Korean apparel retailer E-land is successfully operating 9 fashion brands in China (Park 2007), and the sales volume of its over 2,400 stores in 182 cities in China has increased about 30\% every year for the past 10 years (Yong 2012). MUJI from Japan, which appeals to consumers with distributing unique minimal design apparel and lifestyle products (Curry 2008), is also expanding quickly in multiple countries including the new entries to 8 Asian countries, 11 European countries, and the United States (MUJI website). Regarding this trend, what would be the best positioning element for the global brands having Western-origins in the emerging Asian markets? With the growing presence of Asian brands in the global marketplace, the global brands with Western-origins need to observe what strategies the Asian 
competitors are pursuing in Asian markets based on their advantages of experiential knowledge in Asia. In this sense, this study was an early attempt to show the Asian brands' current progress of internationalization. Now the brands with Western-origins need to consider what kinds of their differential competitive advantages can beat the Asian competitors' experiential knowledge in emerging Asian markets; for instance, as Giordano and Uniqlo concentrated on the basic causal wear concept by avoiding the same concept of global fast fashion.

\section{Limitations and future studies}

First, this paper assessed only publically available secondary resources because more access to companies' internal information was limited. Therefore, the results of this study should be generalized carefully in evaluating Giordano and Uniqlo's international business performances.

Also, only two pioneer Asian apparel brands, Giordano and Uniqlo, were selected in the present study. Although a case study approach allows looking at the selected brands closely, other Asian brands are also currently growing as mentioned in discussion. Therefore, future studies on the other Asian brands will be important additional empirical evidences of Asian apparel brands' internationalization. In this sense, generalizing the Giordano and Uniqlo's cases to the other Asian apparel brands should take a careful consideration.

In addition, due to the limitation of secondary data available to the public, this study mainly focused on the foreign market entries and patterns in the two brands' internationalization, but there are other topics that can be additionally assessed. For example, comparing the market entry mode (e.g., wholly-owned operation, joint venture, licensing, etc.) or relating the entry mode to actual performances in international markets will be another topic. More specifically, although Giordano and Uniqlo showed common internationalization patterns, their selection of entry modes and strategic focuses (e.g., focusing on duty-free shops verses global flagship stores) might differ. Therefore, comparing the future success of the two brands' different strategies would be promising for future studies.

Acknowledgement

Authors appreciate the associate editor, Dr. Yoon-Jung Lee, for her guidance and endeavors in developing this manuscript.

\section{Referred websites}

Fast Retailing website. http://www.fastretailing.com/eng/

Giordano website. http://www.giordano.com.hk/HK/index.html

MUJI website. http://www.muji.us/about-muji/

Received: 22 January 2014 Accepted: 15 April 2014

Published online: 04 July 2014

References

Agarwal, S, \& Ramaswami, SN. (1992). Choice of foreign market entry mode: impact of ownership, location and internalization factors. Journal of International business studies, 23(1), 1-27.

Andersen, O. (1997). Internationalization and market entry mode: a review of theories and conceptual frameworks. Management International Review, 37, 27-42.

Andersen, O, \& Kheam, L. (1998). Resource-based theory and international growth strategies: an exploratory study. International Business Review, 7(2), 163-184.

Bell, J, McNaughton, R, \& Young, S. (2001). 'Born-again global' firms: an extension to the 'born-again' phenomenon. Journal of International Management, 7(3), 173-189.

Bhardwaj, V, Eickman, M, \& Runyan, R. (2011). A case study on the internationalization process of a 'born-global' fashion retailer. The International Review of Retail, Distribution and Consumer Research, 21(3), 293-307. 
Childs, ML, \& Jin, B. (2014). Is Uppsala model valid to fashion retailers? An analysis from internationalisation patterns of fast fashion retailers. Journal of Fashion Marketing and Management, 18(1), 36-51.

Conti, S. (2011). Uniqlo Sets Expansion, Focuses on Innovation (Women's Wear Daily). retrieved from http://www.wwd. com/wwd-publications/wwd/2011-09-29/.

Curry, M. (2008). The Post-Materialist: MUJl Obsession. The New York Times Style magazine. retrieved from http:// tmagazine.blogs.nytimes.com/2008/06/06/the-post-materialist-muji-obsession/.

Datamonitor. (2009). Global Apparel and Textiles (Report of Industry Profile). Retrieved from http://prendasinteligentes. wikispaces.com/file/view/globa+textil.pdf.

Dibb, S. (1996). The impact of the changing marketing environment in the Pacific Rim: four case studies. International Journal of Retail \& Distribution Management, 24(11), 16-29.

Dunning, JH. (1977). Trade, Location of Economic Activity and the MNE: A Search for an Eclectic Approach. In O. Bertil et al. (Eds.), Proceeding of Noble Symposium at The International Allocation of Economic Activity. Stockholm, London.

Dunning, JH. (1988). The eclectic paradigm of international production: a restatement and some possible extensions. Journal of International Business Studies, 19(1), 1-31.

Economist. (2010). Uniquely positioned. Economist. Retrieved from http://www.economist.com/node/16436304.

Forsgren, M. (2002). The concept of learning in the Uppsala internationalization process model: a critical review. International Business Review, 11(3), 257-277.

Giordano Annual Report. (2012). Retrieved from http://www.giordano.com.hk/HK/investors/R2012/e00709-AR\%202012.pdf. Giordano Interim Report. (2011). Retrieved from http://www.giordano.com.hk/HK/investors/finReportsMain.html.

Giordano Interim Report. (2013). Retrieved from http://www.giordano.com.hk/HK/investors/finReportsMain.html.

Goworek, H. (2007). Product Assortment. In H. Goworek (Ed.), Fashion Buying (2nd ed., p. 102). Oxford, UK: Blackwell Publishing.

Dickler, J. (2011). Uniqlo opening 5th Ave. flagship store in big U.S. push. CNN Money. Retrieved from http://money. cnn.com/2011/10/13/pf/uniqlo/.

Hayes, SG, \& Jones, N. (2006). Fast fashion: a financial snapshot. Journal of Fashion Marketing and Management, 10(3), 282-300.

Jackson, P, \& Sparks, L. (2005). Retail internationalization: Marks and Spencer in Hong Kong. International Journal of Retail and Distribution Management, 33(10), 766-783.

Johanson, J, \& Vahlne, JE. (1977). Internationalization process of firm - model of knowledge development and increasing foreign market commitments. Journal of International Business Studies, 8(1), 23-32.

Johanson, J, \& Vahlne, JE. (1990). The mechanisms of internationalization. International Marketing Review, 7(4), 11-24.

Khandelwal, PK, \& Saxena, RP. (2010). Is the magic of "feel good" and "look great" at Giordano still working? Management Decision, 48(3), 440-455.

Kim, M. K. (2010). Marketing strategy and the current status of global SPA brands. Journal of Fashion Business, 14(3), 35-51.

Lopez, C, \& Fan, Y. (2009). Internationalization of the Spanish fashion brand Zara. Journal of Fashion Marketing and Management, 13(2), 279-296.

Meshbah, R. (2010). Back to Basic Strategy Pays Off for Giordano. AME Middle East Business Resource. Retrieved from http://www.ameinfo.com/blog/management/giordano-middle-east/back-to-basics-strategy-pays-off-for-giordano/.

Park, J. J. (2007). Korean Apparel Industry's 21th Century Survival Strategies. Korea weekly. Retrieved from http://weekly. hankooki.com/lpage/cover/200704/wk2007041815205482190.htm.

Seno, AA. (1999). An All-New Dress for Success: Giordano is Out to Remake Itself Before Big Global Retailers Like the Gap Arrive for a Showdown. Asia Week.com. Retrieved from http://www-cgi.cnn.com/ASIANOW/asiaweek/magazine/99/ 1015/biz_giordano.html.

Truong, P. (2011). Uniglo Fifth Avenue Opening: Company Launches Biggest Location Ever. International Business Times. Retrieved from http://www.ibtimes.com/articles/230776/20111013/uniqlo-fifth-avenue-opening.htm.

Uniqlo Annual Report. (2010). Retrieved from http://www.fastretailing.com/eng/ir/library/annual.html.

Uniqlo Annual Report. (2013). Retrieved from http://www.fastretailing.com/eng/ir/library/annual.html.

Vrontis, D, \& Vronti, P. (2004). Levi Strauss: an international marketing investigation. Journal of Fashion Marketing and Management, 8(4), 389-398.

Welch, LS, \& Luostarinen, R. (1988). Internationalization: evolution of a concept. Journal of General Management, 34, 34-57.

Wigley, S, \& Chiang, C.-L. R. (2009). Retail internationalization in practice: Per una in the UK and Taiwan. International Journal of Retail \& Distribution Management, 37(3), 250-270.

Wigley, SM, Moor, CM, \& Birtwhistle, G. (2005). Product and brand: critical success factors in the internationalization of a fashion retailer. International Journal of Retail \& Distribution Management, 33(7), 531-544.

Wirtz, J, Lovelock, C, \& Wirtz, J. (2007). Giordano: Positioning for International Expansion. In Service Marketing: People, Technology, Strategy (6th ed., pp. 511-519). NJ: Pearson Prentice-Hall.

Yong, HJ. (2012). Case Study: The Reason Why China is Hooked by E-land. Meil Kyungje. Retrieved from http://news.mk. co.kr/newsRead.php?year $=2012 \&$ no $=13623$.

Zhao, XM, \& Decker, R. (2004). Choice of Foreign Market Entry Mode: Cognitions from Empirical and Theoretical Studies (Diskussionspapier - Fakultät für Wirtschaftswissenschaften, Universität Bielefeld, 512). Bielefeld: Universität Bielefeld.

doi:10.1186/s40691-014-0004-7

Cite this article as: Woo and Jin: Asian apparel brands' internationalization: the application of theories to the cases of Giordano and Uniqlo. Fashion and Textiles 2014 1:4. 